\title{
The Use of Token Economy Technique to Reduce The Impulsive Behavior of Children with Low Autistic Level in SMP Negeri 14 Banjarbaru
}

\author{
Dwi Amilia Oktaviani, Chairil Faif Pasani, Eviani Damastuti \\ Special Education Program \\ Universitas Lambung Mangkurat \\ Banjarmasin, Indonesia \\ dwi.amiilia@gmail.com
}

\begin{abstract}
Autistic children generally have complex obstacles in terms of communication, social interaction and behavior. One of the obstacles in behavior experienced by autistic children is the lack of ability to sort out appropriate and inappropriate behavior to do, that it can trigger impulsive behavior. Impulsive behaviors, in this study, means not able to sit down quietly for a long time, shout if the class feels quite quiet, and do the task in a hurry without paying attention to the commands. Therefore, it is necessary to give a treatment to reduce this behavior, namely the token economy technique. The purpose of this study is to find out the use of token economy technique to reduce impulsive behavior of a student with low autism level in SMP Negeri 14 Banjarbaru. This study used quantitative approach with the SSR method (Single Subject Study), using the design A1-B-A2, where A1 is the baseline $1, B$ is the intervention and $A 2$ is the baseline 2 . The subject in this study is a student in class VIIIA who has low autistic obstacles. The data was collected by doing direct observation and documentation of this study by recording events (frequency). Data was analyzed using graphical visual analysis technique (Visual Analysis of Graph Data) by plotting the data into the graph, and then the data was analyzed by components in each A1-B-A2 condition. The results showed a decrease in impulsive behavior of the student in SMP Negeri 14 Banjarbaru after applying token economy technique. The results obtained at baseline 1 (A1) are 14 times the occurrence of impulsive behavior, intervention (B) is 10 times which shows the impulsive behavior of children begins to decline and at baseline 2 (A2) is 9 times. The estimated trend tends to improve, decreases mean level from baseline 1 (A1) to baseline 2 (A2).
\end{abstract}

Keywords-token economy technique; impulsive behavior; children with low autism level

\section{INTRODUCTION}

Children with special needs or extraordinary children, according to reference [1], are children who are significantly different in several important dimensions of their humanitarian functions. Those who are physically, psychologically, cognitively, or socially inhibited in achieving their goals or needs and potential to the fullest, including those who cannot hear, cannot see, have speech impairments, disabilities, mental retardation, emotional disturbances and also gifted children with high intelligence, can be categorized as special or extraordinary children. It is because they require skilled handling of professional personnel. Based on the classification, children with special needs are classified into visual impairment, hearing impairment, mentally disabled, quadriplegic, learning difficulties, $A D H D$, slow learner, specific learning difficulties and autism.

Autism, according to Mudjito in reference [2], is children who experience communication and social interaction disorders and experience sensory disorders, play patterns, and emotions. The reason is because the network and brain function are not synchronized. Some are progressing rapidly, while others are mediocre. The behavior of autistic children is a typical behavior that is easily recognized invisibly from the behavioral aspects of autistic children such as hyperactive and hypoactive, besides stereotypical behavior or other behaviors. Autistic behavior is generally caused by children's limitations in social interaction or communication. The things that become the limitation of the autistic child can lead to the occurrence of impulsive behavior.

Impulsive behavior, according to reference [3], is defined as behavior that tends to be destructive and uncontrolled. Impulsive behavior in school-age children according to teacher's perception refers to children who act spontaneously without thinking at the beginning. For example, working on a task without learning the instructions surely leads to the wrong results. Impulsive behavior in children with autism which often appear is like not able to sit quietly in the classroom for a long time. The child will appear restless and even leave the classroom, shout when the class feels calm and rushed in doing the task.

Based on observations that have been conducted at SMP Negeri 14 Banjarbaru, researchers found a student who was identified having low autism. The child showed undesirable behaviors, such as shouting while in class, disturbing friends who were studying and not being able to sit still for long periods of time, and being hurry in doing the tasks which are then considered as a child with impulsive behavior. The tendency of behavior deviations in their daily lives is shown such as: answering without being asked, disturbing friends during the learning process, and hurrying to do the task. From 
these observations, it is necessary to have special treatment to reduce impulsive behavior of the student, considering the condition of child who is able to carry out two-way communication even if only occasionally, the child's ability to carry out the commands given, and the child's interest in an object. To reduce the impulsive behavior, then token economy technique is used.

Token economy is giving one piece (or one sign, one signal) as soon as possible every time after the target behavior appears. These pieces can later be exchanged for objects or reinforcing activities desired by the subject. Soekadji in reference [4] states that token economy is a program that uses pieces or marks that are given as soon as possible whenever the target behavior appears, then the pieces or marks that have been collected can be exchanged with the subject's reward.

Based on the description of the token economy which is originally a behavior modification technique that can also be applied to children with autism to reduce impulsive behavior of children, the researcher is interested in conducting research on, " The Use of Token Economy Technique to Reduce The Impulsive Behavior of A Student with Low Autism Level In Smp Negeri 14 Banjarbaru."

\section{RESEARCH METHOD}

This study used quantitative approach with SSR (Single Subject Research) method using A1-B-A2 design. The subject in this study was a student in class VIIIA who has low autistic level obstacles in SMP Negeri 14 Banjarbaru. Data collection techniques used in this study were direct documentation and observation by recording events (frequencies) regarding impulsive behavior of children before and after being given token economy treatment techniques to reduce impulsive behavior of children. There were 2 variables in this study, namely independent variable and dependent variable. The independent variable is the token economy technique, while the dependent variable is the reduction in impulsive behavior of children. Data was analyzed using graphical visual analysis technique (Visual Analysis of Graph Data) by plotting the data into the graph, and then the data was analyzed based on the components in each A1-B- A2 condition [5].

\section{RESULT AND DISCUSSION}

The frequency of implusive behavior is presented in Table 1.

TABLE I. The FReQuency of INPULSIVE BeHAVIOR ON THE StUdent WITH A1-B-A2 CONDITION

\begin{tabular}{|l|l|l|l|l|}
\hline \multirow{2}{*}{ No. } & Condition & Session & Day/Date & $\begin{array}{c}\text { Numbers of } \\
\text { Events with the } \\
\text { Occurrence of } \\
\text { Impulsive } \\
\text { Behavior }\end{array}$ \\
\hline \multirow{4}{*}{1} & Baseline $\left(\mathrm{A}_{1}\right)$ & 1 & 19 March 2018 & 14 \\
\cline { 3 - 5 } & & 2 & 20 March 2018 & 14 \\
\cline { 3 - 5 } & & 3 & 21 March 2018 & 13 \\
\cline { 3 - 5 } & & 4 & 22 March 2018 & 14 \\
\cline { 3 - 5 } 2 & Intervensi & 5 & 23 March 2018 & 14 \\
\cline { 3 - 5 } & $(\mathrm{B})$ & 7 & 26 March 2018 & 11 \\
\hline
\end{tabular}

\begin{tabular}{|l|l|l|l|l|}
\hline \multirow{2}{*}{} & & 8 & 28 March 2018 & 10 \\
\cline { 3 - 5 } & & 9 & 29 March 2018 & 9 \\
\hline \multirow{4}{*}{3} & Baseline $\left(\mathrm{A}_{2}\right)$ & 10 & 2 April 2018 & 9 \\
\cline { 3 - 5 } & & 11 & 3 April 2018 & 9 \\
\cline { 3 - 5 } & & 12 & 4 April 2018 & 9 \\
\cline { 3 - 5 } & & 13 & 5 April 2018 & 9 \\
\hline
\end{tabular}

In the baseline phase 1 (A1) there were 5 sessions which occupied 60 minutes in every session, and the results obtained from each session were the frequency of impulsive behavior appearing on the subject during the session. The impulsive behavior in this study is the behavior of not being able to sit down quietly for a long time, shouting when the class is quite enough, and doing the task in a hurry without paying attention to the command. The results obtained in the first session were 14 times, in the second session 14 times, the third session 13 times, the fourth session returned to 14 times, and the fifth session remained at 14 times. The high impulsive behavior at baseline 1 (A1) was because researchers have not given treatment, meaning that researchers only collect the initial data to be used as a comparison or reference to the success or failure of this study. Impulsive behavior in children with autism, according to reference [3], is caused by severe developmental disorders which affect the way a person communicates and reacts (relates) to others since people with autism are unable to communicate verbally or non-verbally which causes them only interested in their own world. It can be seen from the problem of impulsive behavior of children which is maladaptive behavior, such as the occurrence of meaningless behavior such as children sitting around repeatedly in a period of time that causes children get hard to do the learning process because the child is not ready for the learning process.

In the Intervention phase (B), there were 4 sessions which took 60 minutes long in every session. The results obtained from each session are the frequency of impulsive behavior appearing on the subject during the session. The session in the intervention phase (B) was a continuation of the session in the baseline phase 1 (A1). The results obtained from the sixth session were 11 times, the seventh session dropped to 10 times, the eighth session remained 10 times, and in the ninth session it dropped to 9 times. The reduction of impulsive behavior in the intervention phase (B) is because in this phase the researcher gave treatment in the form of token economy technique which aims to reduce the subject's impulsive behavior. Token economy is a behavior modification technique by giving one piece (or one sign, one signal) as soon as possible every time the target behavior appears. These pieces can later be exchanged with the objects or other reinforcing activities that the subject wants. Other inmates are often called ideal dreamers [4]. Giving tokens according to researchers is very suitable for children with autism because children with autism usually rely heavily on visual senses or vision compared to other senses. Giving tokens when desired behavior arises can improve children's understanding of adaptive behavior. Therefore, in this study, researchers used token economy technique to reduce impulsive behavior in children with autism.

In the baseline phase 2 (A2), there were 4 sessions in which each session took 60 minutes long. The results obtained from each session are the frequency of impulsive behavior appearing 
on the subject during the session. The session in the baseline phase 2 (A2) was a continuation of the previous session namely baseline 1 (A1) and intervention (B). Then the result obtained from the tenth session was 9 times, the eleventh session was 9 times, the twelfth session was times, and the thirteenth session remained 9 times. Impulsive behavior tends to be leveled off, does not increase or decrease because the treatment is not given in the form of token economy technique, but when compared with baseline phase 1 (A1), the occurrence of impulsive behavior of the child at baseline 2 (A2) tends to be lower.

\section{CONCLUSION}

In this study, it can be concluded that the use of token economy technique is able to reduce the impulsive behavior on children with low autistic level in SMP Negeri 14 Banjarbaru.

\section{REFERENCES}

[1] Hasdianah, Autis pada Anak (Pencegahan, Perawatan, dan Pengobatan). Yogyakarta: Nuha Medika, 2013.

[2] E. Kosasih, Cara Bijak Memahami Anak Berkebutuhan Khusus. Bandung: Yrama Widya, 2012.

[3] D. Koswara, Pendidikan Anak Berkebutuhan Khusus Autis. Jakarta: PT. Luxima Metro Media, 2013.

[4] E. Purwanta, Modifikasi Perilaku Alternatif Penanganan Anak Berkebutuhan Khusus. Yogyakarta: Pustaka Pelajar, 2012.

[5] J. Sunanto, K. Takeuchi, and H. Nakata, Pengantar Penelitian dengan Subyek Tunggal. CRICED: Universty of Tsukuba, 2005. 